\title{
Yield Gap Associated with Crop Management in Wheat (Case Study: Ardabil Province-Parsabad Moghan)
}

\author{
Asgar Shirinzadeh ${ }^{(1)}$, Hossein Heidari Sharif Abad ${ }^{(1) \#}$, Ghorban Nourmohammadi ${ }^{(1)}$, \\ Eslam Majidi Haravan ${ }^{(1)}$ and Hamid Madani ${ }^{(2)}$ \\ (1)Department of Agronomy, Science and Research Branch, Islamic Azad University, \\ Tehran, Iran; (2) Department of Agronomy, Arak Branch, Islamic Azad University, \\ Arak, Iran.
}

\begin{abstract}
$\mathbf{T}$ O INVESTIGATE the factors affecting irrigated wheat yield loss, compared to the attainable yield, a non systematic survey experiment was conducted in 60 fields in the city of Parsabad-Moghan, during two years 2013-2014 and 2014-2015 using Comparative Performance Analysis (CPA). Sampling of wheat fields was performed randomly from 5 different points of each farm using a square meter. All the information about management operations, soil and crop characteristics including seed bed preparation, planting date, varieties and their site preparation, seed rate, planting ways, weeds control ways, amount and timing of herbicides and fungicide use and wheat harvest time were recorded during a seasonal year using questionnaire. At the end of the seasonal year, the actual yield harvested by farmer's was recorded. Among the various parameters, planting time, spike density, the number of split application of urea, land preparation operations, farmer experience and repeated use of fungicides had significant effects on wheat yield. The results showed that the average actual yield $(6431.85 \mathrm{~kg} / \mathrm{ha})$ and attainable yield $(8749.27 \mathrm{~kg} / \mathrm{ha})$, were different with a gap of $2317.42 \mathrm{~kg}$ per hectare. The share of each of the factors were: Wheat planting time of yield gap 18\%, spike density, 29\%, the split application of urea $20 \%$, land preparation operations $4.6 \%$, farmer experience $14.3 \%$, repeated use of fungicides $13.4 \%$. The improvisation cases referred above can reduced yield gap and increase yield to more than 8.7 ton/ha.
\end{abstract}

Keywords: Actual yield, Attainable yield, Agronomic management, Wheat, Yield gap.

\section{Introduction}

Due to different involving factors like various diet conditions, destruction of arable land, growing competitive struggles for water and energy and many other factors, the security of food industry has become vulnerable (Ray et al., 2013 and Sharma et al., 2012). Ensuring sufficient food production has been an important challenge throughout the world. A great number of international organizations are cooperating to find a way to fulfill human need to food and at the same time to conserve land quality for coming generations. Having good knowledge of land and production management should be a necessary task for users of agricultural lands and decision makers as well. In order to meet the need to increasing demand for food, it is still significant to use a system to control yield gap close (Kayiranga, 2006).
Farmers everywhere are seeking to improve their life quality by increasing household welfare, such as food security and their earnings, but when they want to adopt technology, they face so many obstacles. That's why many studies about yield gap have tried to realize constrictions causing this failure resulting in increased yield gap in comparison with they expect from analysis of economics and risk avoiding plans (Fischer et al., 2014). One of the strategies which may solve this problem is quantify the production potentiality of farmland in order to determine ways to boost the yield of main crops (Patrignani et al., 2014). This can be done by applying high yielding management practices (Yang et al., 2008) and closing yield gaps between farmers' actual yield and potential yield (Cassman et al., 2003; Licker et al., 2010; Tilman et al., 2011 and Mueller et al., 2012). Yield gap closing has been a slow process in general. Taking this, during

"Corresponding author email: h.heidari1871@hotmail.com 
the past 20 years, average differences between annual international rates increases in farm and in potential yield were only $0.5 \%$ of farm yield (Fischer et al., 2014).

Yield gap is referred to as the diversion of yield on experimental station and actual yield in the fields. Interfering factors for yield gap is known as yield constraints (De Bie, 2000). For many researchers, yield gap has been a challenge as a factor narrowing yield. According to De Bie (2000), yield gap can have at least two attributes. It can have minimum of two attributes. The main factor which refers to general not transferable as the environmental condition and some internal technologies which are in hand at research stations. This parameter is the main difference in management practices. The second component of yield gaps in mainly the result of differences is management practices. When farmers apply suboptimal doses of inputs and excessive cultural practices, management gaps start to arise. The second form of yield gap can be managed which can be narrowed by applying more endeavor in terms of research and extention services beside appropriate intervention from government authorities.

Decreasing yield gaps in main crops using effective management operations can cause the production to be improved, beside giving environmental and economic benefits. Investigating the yield gaps in the aimed crops can lead to better understanding of yield variability, yield capacity, and the input effectiveness of these crops may reveal suitable pathways for boosting agricultural efficiencies (Fischer et al., 2009; Carberry et al., 2011 and Van Ittersum et al., 2013).

CPA is one of the methods used to quantify the yield gap. Using this method, the main yield limitations and some quantified functions for the yield gap are determined. In the comparative analysis using multiple regression and stepwise analysis (Rezaie \& Soltani, 2007) function limitations, and consequently production model will be determined. Understanding the functional limitations can help us in trying to reduce yield gap. Reducing the yield gap not only helps to increase yield and production, but also improves the working efficiency of land use, reduce production costs and increase yield stability (Torabi et al., 2011). For prosperous CPA, the investigations must concentrate on specific land use class and the system of land use under survey must be reflected the whole prevailing range of environment condition and different technology use. Appearing in a specific area of study CPA considers the different conditions of the environment aspects (De Bie, 2000).

Yield gaps in a region and among farming households can be related to management in agronomic practices (Fanadzo et al., 2011). Realization of farming management practices in Moghan is therefore a main input point by the aim of boosting food fruitfulness and decreasing within site yield gap. This study suggests an agronomic study method which is used to determine yield gap and variability in wheat grain yield among different farms and identify the key affecting factors in order to improving strategies. For instance, local-level grain yield measuring along with the assessment of management practices are necessary to find the main causes and opportunities.

The study aimed to (I) Demonstrate an approach for farm level agronomic survey, quantify the gap between current and attainable yields for Wheat in the Pars Abad Moghan, (II) Quantify production constraints that contributes to the current yield gap and (III) Increase wheat yields through agronomic means in different wheat cultivars in Pars Abad Moghan.

\section{Materials and Methods}

This research was carried out at the Agricultural and Natural Resources Research Center of Ardebil Province (Fig. 1) in northwestern Iran $\left(39^{\circ} 41^{\prime} \mathrm{N}\right.$ and $47^{\circ} 32^{\prime} \mathrm{E}$; altitude: 45-50masl). Weather data (precipitation and air temperatures and Humidity) were obtained from a meteorological station situated at the same location where the trial took place and reported as mean decade data, together with 26 year averages for temperature and precipitation (Fig. 2). According to the Pars Abad, Moghan, synoptic station, it is a semi-arid region with mild winters and hot summers. The maximum and minimum temperature was $37^{\circ} \mathrm{C}$ in June and $-13.2^{\circ} \mathrm{C}$ in January. The average rainfall was $317 \mathrm{~mm}$ and relative humidity was $76 \%$ according to the meteorological information during these two years of experiments. 


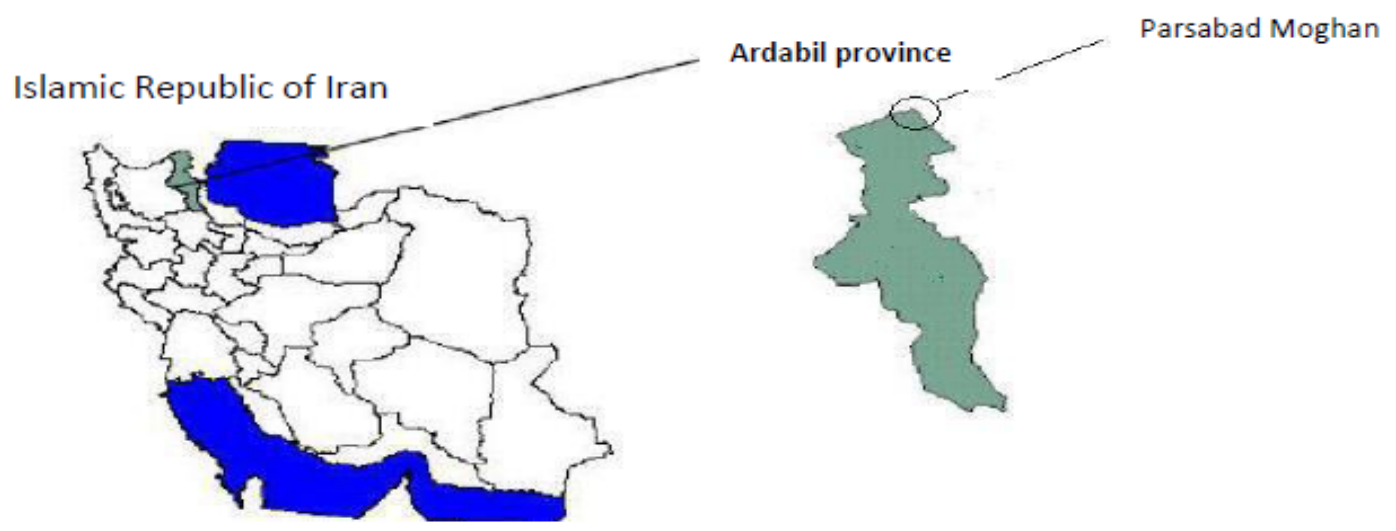

Fig. 1. Location of Parsabad Moghan Basin in Ardabil province, Iran.

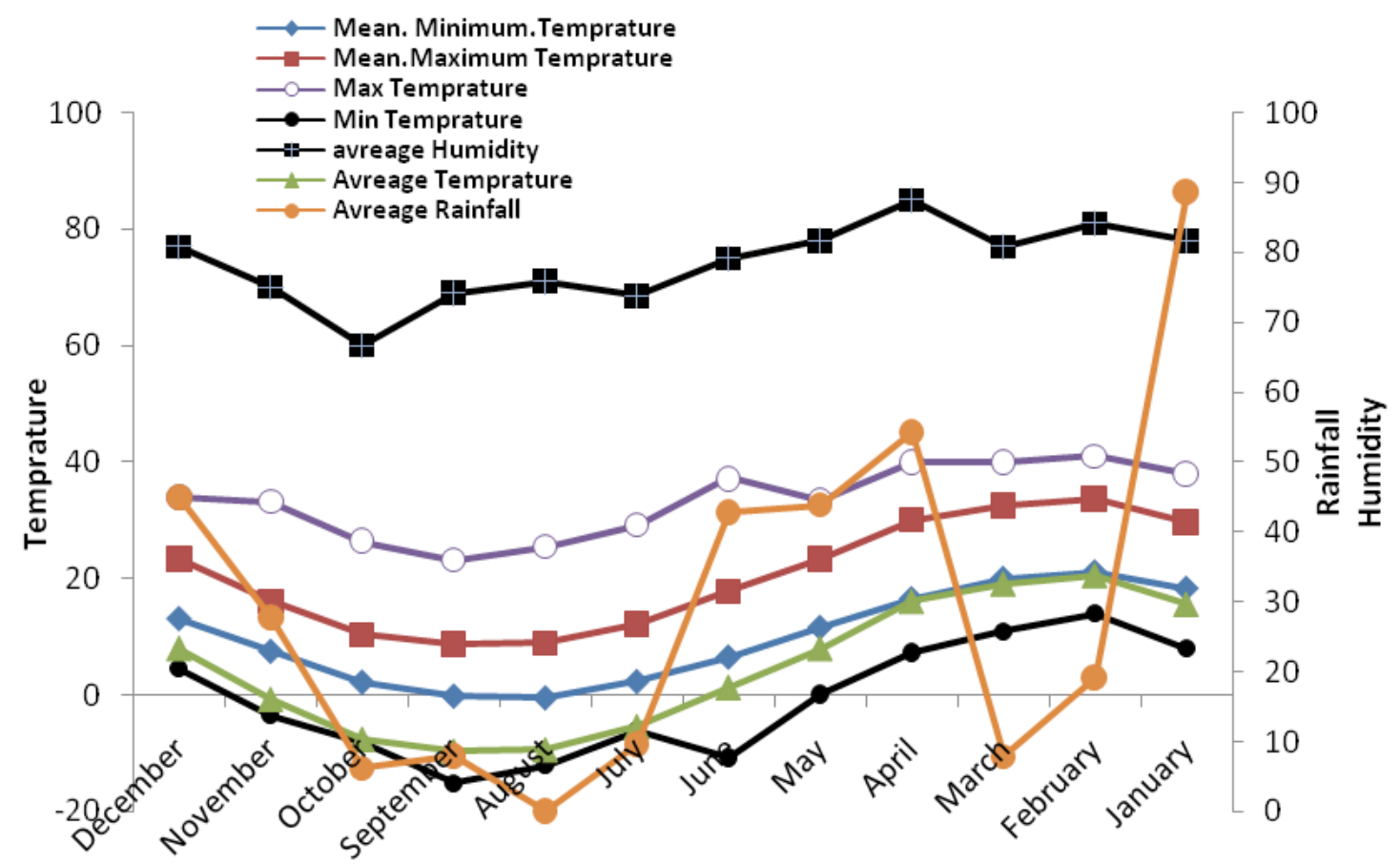

Fig. 2. Long-term average of monthly maximum, minimum and mean temperature $\left({ }^{\circ} \mathrm{C}\right)$, Rainfall and humidity recorded during the period 1989-2015. (Arrows indicate the growing period of wheat (October-June) in these areas).

\section{Data collection and research method}

Sixty farms were selected for two consecutive years (2013-2015) and all necessary information to the survey was collected from the farms. Selected farm management practices, including seed bed preparation, operation (including planting, irrigation and weed fight) and harvested were done under the supervision of experts for wheat. Despite, conditions of the farms were diverse in operation management. Information on physical and chemical properties of soil, data management, including the preparation of planting bed (type, number and timing of plowing, etc.), the use and location of formulated packages, planting, fertilizer (type of fertilizer nitrogen rate and the number of using fertilizer), weed fight, pests and diseases, including type of toxin and the toxin intake, number and timing of irrigation, harvest time, information on crops including registration and performance measurement and yield components, the stem elongation, heading, pollination and grain filling and the leaf area index of selected plants from each field (10 plants randomly) were calculate and recorded. To determine the yield, the relationship between all variables (qualitative and quantitative, qualitative variables were coded as zero and one) 
were measured and performance through stepwise regression method (Torabi et al., 2011) were examined. The final model was determined by the controlled trial and error method, which could quantify the functional limitations. By putting the average observed variable (Xs) in 60 farms of the study, the model calculated the average performance. Then by putting the observed value of the variables in the model, the maximum attainable yield was calculated. The difference between the two was considered as the yield gap. Yield gap ratio for each variable represents the contribution of each variable's performance to total yield gap which is shown in percent in Table 1. SPSS software was used to analyze the data. The research method is shown in flow chart (Fig. 3).

\section{$\underline{\text { Results and Discussion }}$}

\section{Temporal trend of wheat yield}

The Fig. 4 shows the temporal trend (19962015) of local wheat yield and production level. Based on this figure, a high variability in the wheat yield is observed over the years. Many farmers are not aware of the causes of yield variability. The increase in production was mostly due to the increase in the area under cultivation in the region. During this period, grain yield has been decreasing.

\section{Descriptive statistics}

Figure 5 shows the distribution of yield data. In order to test normality, the 60 yield data obtained were subjected to descriptive analysis. This is done to fulfill the assumption of regression analysis since dependable variable must have a normal distribution. There are some sufficient statistical rationales that data are normally distributed. the p-value for Kolmogorov - Simrnov 2-tail test using as average $6327 \mathrm{~kg} / \mathrm{ha}$ and as standard deviation $1189 \mathrm{~kg} /$ ha had a non-significant probability that data the follow a non-normal distribution, this there is not enough evidence to suggest that the date are not normally distributed. Transformation of the yield date was therefore not required.

\section{Regressions}

A stepwise multiple regressions was performed to obtain a model to determine the kind of management practices that can alter wheat yield variability in an effective way in the experimental area. The most important variables that had a significant impact on yield were used for stepwise multiple regression analysis.

TABLE 1. Quantification of wheat yield gap by yield constraint.

\begin{tabular}{|c|c|c|c|c|c|c|c|}
\hline \multirow[t]{2}{*}{ Variables } & \multirow[t]{2}{*}{ Coefficient } & \multicolumn{4}{|c|}{$\begin{array}{l}\text { Measured amount in Measured amount in } \\
\text { the farm }\end{array}$} & \multicolumn{2}{|c|}{ Gap } \\
\hline & & Average & $\begin{array}{l}\text { Optimum } \\
\text { amount }\end{array}$ & Average & $\begin{array}{l}\text { Selected } \\
\text { amount }\end{array}$ & $\begin{array}{c}\text { amount } \\
\text { (kg/ha) }\end{array}$ & $\%$ \\
\hline Intercept & 7254.22 & 1 & 1 & 7254.22 & 7254.22 & 0 & 0 \\
\hline Planting date & -17.98 & 73.22 & 50 & -1316.5 & -899 & -417.5 & 18 \\
\hline Spike density & 3.8 & 486.3 & 668 & 1847.94 & 2538.4 & 690.46 & 29.7 \\
\hline Number of split fertilizer or Urea & 422.21 & 1.95 & 3 & 862.31 & 1326.63 & 464.32 & 20 \\
\hline $\begin{array}{l}\text { The number of operations to prepare } \\
\text { the land }\end{array}$ & 268.43 & 5.43 & 5 & -1449.52 & -1342.15 & -107.37 & 4.6 \\
\hline Farmer's experience & -21.39 & 47.52 & 32 & -1016.45 & -684.48 & -331.97 & 14.3 \\
\hline Number of repetitions fungicides & 182.68 & 1.3 & 3 & 237.48 & 548.04 & 310.57 & 13.4 \\
\hline Average yield(kg/ha) & - & 6327 & 8600 & - & - & - & - \\
\hline Estimated yields(kg/ha) & $-\square$ & - & - & 6431.85 & 8749.27 & & - \\
\hline Estimated yield gap & $-\square$ & - & - & - & - & 2317.42 & 100 \\
\hline
\end{tabular}




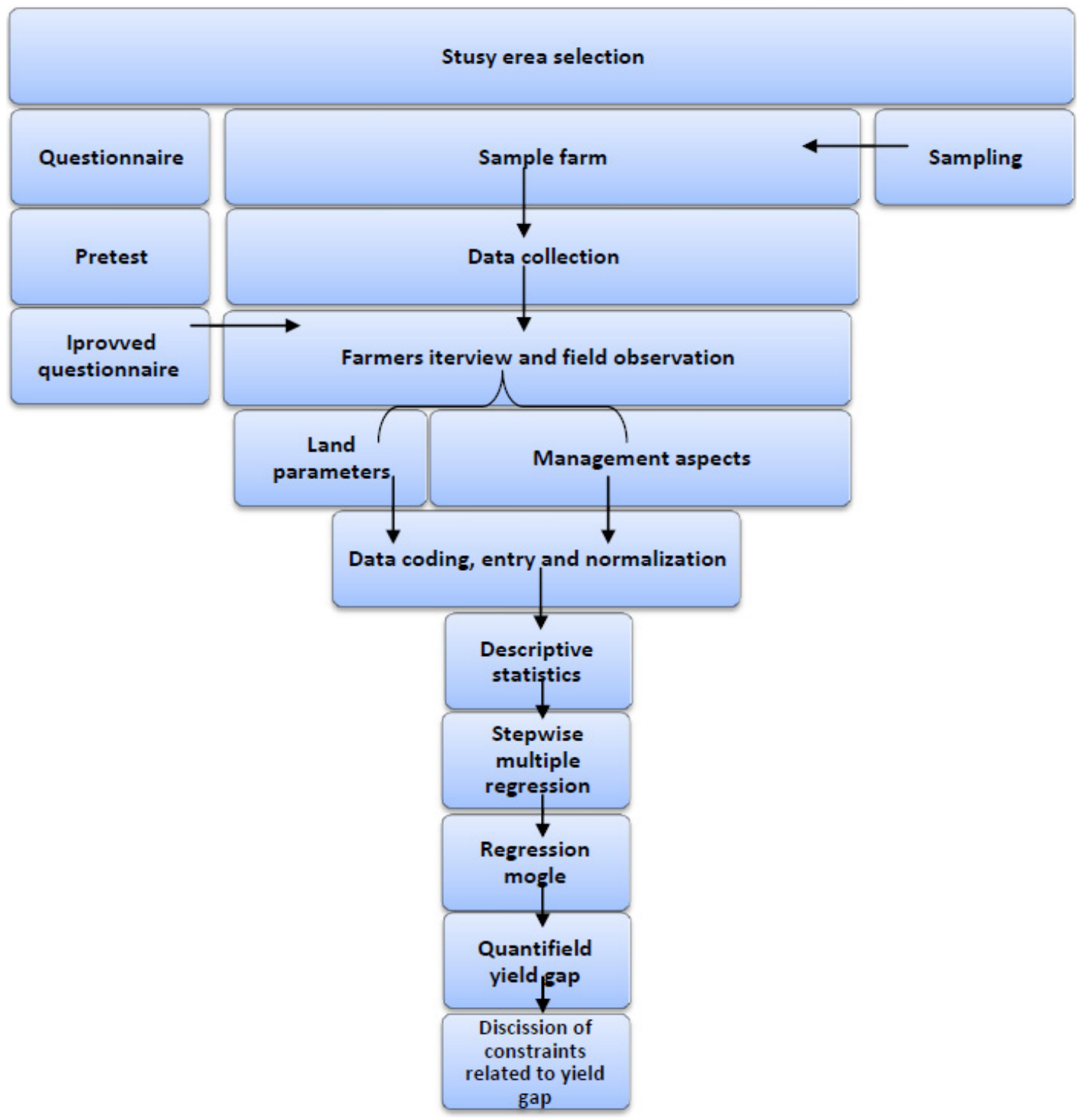

Fig. 3. Flow chart of research method.
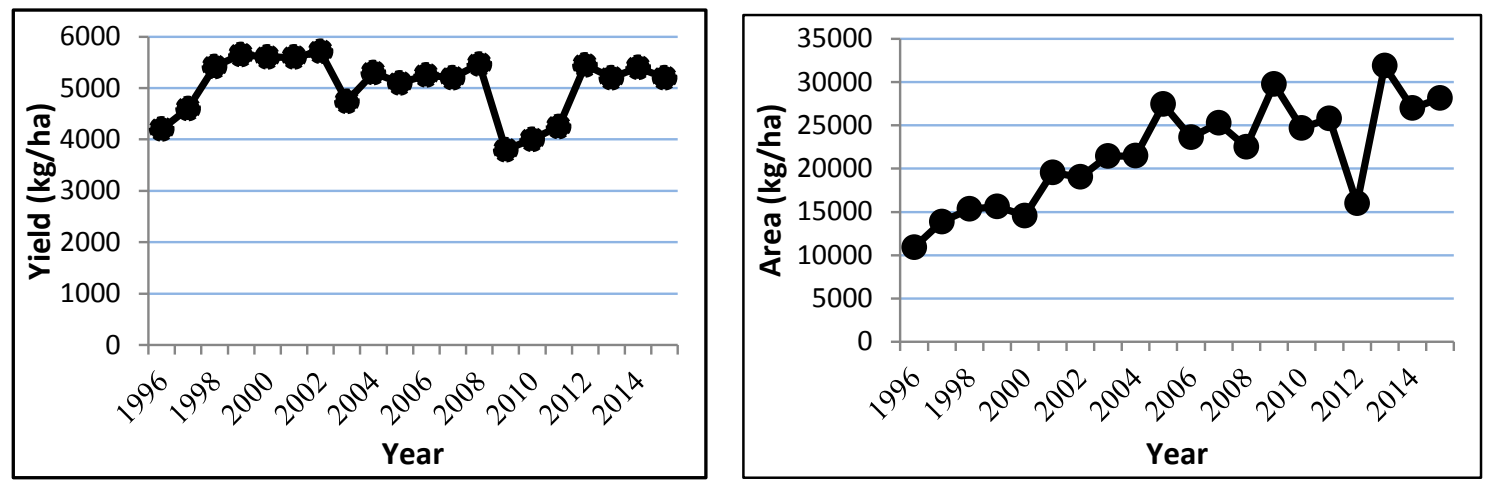

Fig. 4. Temporal trend of wheat yield and area in Parsabad Moghan, data source (Agricultural Organization of Ardabil, 2015). 

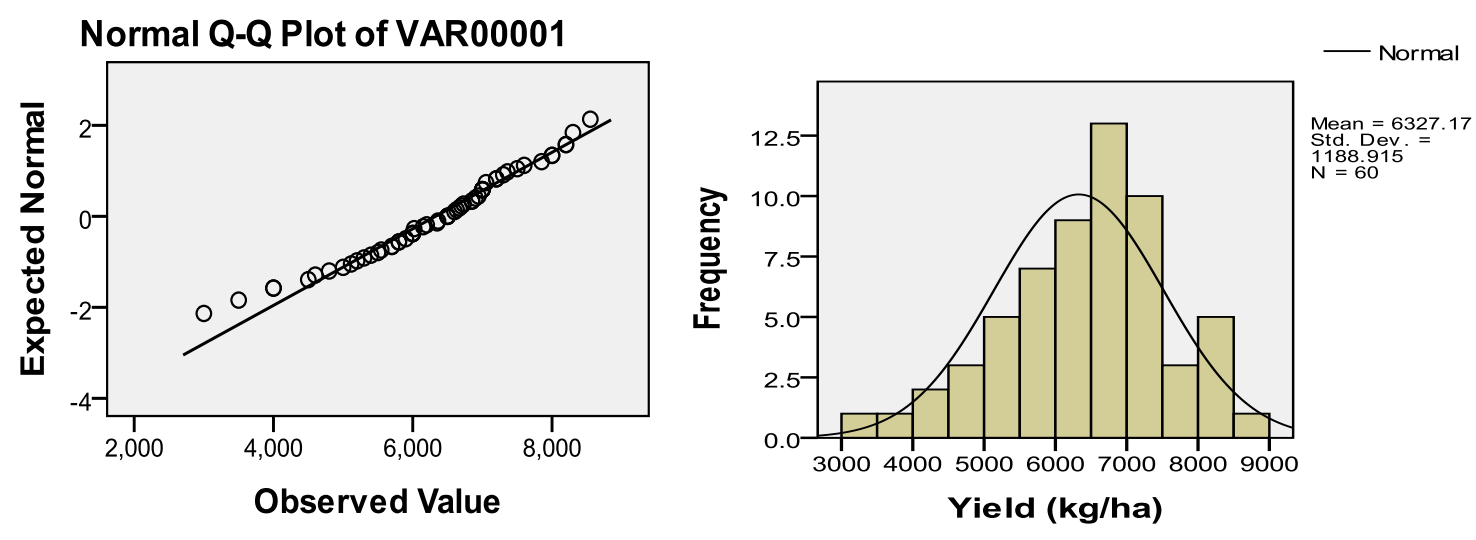

Fig. 5. Right: Distribution of yield date and fitted normal distribution curve and Left: Normality test for yield date.

Production models and yield gap by yield constraints

In this regression, the yield per unit area was considered as the dependent variable and other variables such as planting date, spike density, using urea, preparation of the land, the farmer's experience and the number of repetitions of fungicides were used as independent variables. The results can be seen in equation. Finally, using this equation, the actual yield, the attainable yield and the contribution of each variable to reduce performance were determined.

$\mathrm{Y}(\mathrm{kg} / \mathrm{ha})=7254.22-17.98(\mathrm{PD})+3.8(\mathrm{SD})+422.21$ (NSF)-268.43 (NOP)-21.39 (FEP)+182.68 (NRF)

where: Y is yield, PD: Planting date, SD: Spike density, NSU: The number of split fertilizer or urea, NOP: The number of operations to prepare the land, FEP: Farmer's experience and NRF: The number of repetitions fungicides.
Figure 6 conveys the relationship between the obtained actual and estimated yield having correlation coefficient $(\mathrm{R}=0.94$, significant at $0.01, \mathrm{P}=0.000)$. Standard error and coefficient variation $(\mathrm{CV})$ are $458 \mathrm{~kg} / \mathrm{ha}$ and $7 \%$, respectively. These statistics shows that the model has a proper exactness and can be used to determine yield gap and the proportion of each yield constraints.

Table 1 shows the estimate yield gap $(\mathrm{kg} /$ ha) and the proportions' of each yield limitation factors to the overall yield gap. By means of production function and parameter statistics, the average and optimum amount were obtained for each explanatory parameters. The calculate of the relevant attribution are based on comparison of the level of average yield and best yield obtained from investigated plots (60 samples). The difference in yield multiplied by the coefficient suggested by the model indicates the contribution to overall yield gap for each particular variable.

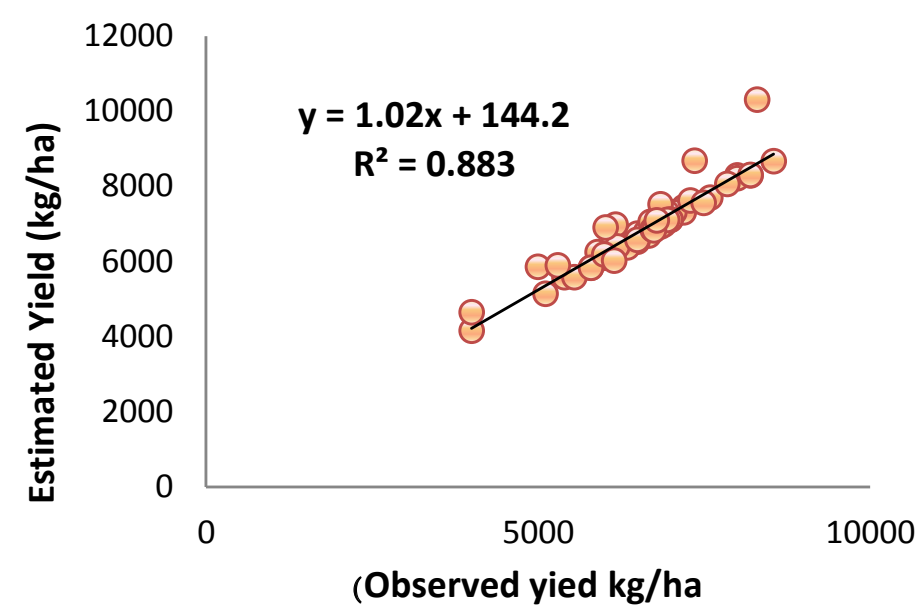

Fig. 6. Relation observed and estimated yield relationship. 
The model estimated maximum and average yield as 8749.27 and $6431.85 \mathrm{~kg}$ per hectare, respectively which shows a consider ability difference. The total estimated yield gap of $2317.42 \mathrm{~kg} / \mathrm{ha}$ appear to be the result of management and biophysical constraint (Fig. $7)$ : Planting time (18\%), spike density (29.7\%), number of split application of urea $(20 \%)$, land preparation operations (4.6\%), farming experience $(14.3 \%)$ and repeated use of fungicides for wheat $13.4 \%$ is verfied.

\section{Yield and planting date}

The analysis of management parameters indicates six major constraints that significantly affect wheat yield in the study area. The average yield gap was $2317.42 \mathrm{~kg} /$ ha (Table 1) due to above factors. Most of farmers in Parsabad Moghan are not aware that they could increase yield by improvement of management practices. Identifying the causes of gaps will provide actionable information to enhance food security. It is obvious that substantial improvement could be determined in wheat yields in Moghan providing that wheat is planted on time and plant stands are good. The results CPA in Table 1 show that planting date with $18 \%$ yield gap is one of the factors that create a gap between actual yield and attainable yield. The model output suggests that if farmers cultivate on 20 November (50 days after the September, their yield increases at a rate of $417.5 \mathrm{~kg}$ per hectare. Farmers in the region plant autumn wheat late and in a bad weather conditions due to poor crop rotation (corn as second crop) leading to late harvesting of maize (late December). These conditions, in turn, increases density and the number of operations required to produce the crop. In Parsabad Moghan, wheat is mainly planted on 38 to 100 days after the first of October. As it can be seen in Fig. 8 by increasing the number of days from the beginning of October, the yield is dropped significantly $(\mathrm{P}<0.01)$.

\section{Planting date and yield gap}

It is well obvious that remarkable increases can be determined in wheat yields in the Moghan if wheat is cultivated on time and plant stands are proper. Doing a pilot project based on a variety of cultivars showed that timely planting can help to improve yield and reduce wheat yield gap. Selection of the most ideal time (November 21) and suitable time November 6 till December 6) for planting in the Moghan region reduced the average yield gap from 2322, respectively to 537 and $1366 \mathrm{~kg} /$ ha (Fig. 9). The results of planting time showed that the optimum planting date in the region (Moghan) is from of November 6 to of December 6.

Mahloji et al. (2000) also investigated the effect of two planting date ( $7^{\text {th }}$ of May and the $7^{\text {th }}$ of July) and water stress on yield and yield components of bean in Isfahan stated that the delay shortens the development phases and also accelerates the ripening time and flowering (vegetative period) resulting in a $29.6 \%$ yield loss. Flowers et al (2006) stated that planting date had a great effect on wheat yield and decreased yield up to $24 \%$. Others stated that the reduction in yield caused by the planting date could be due to the shortening of the grain filling period, the increase in temperature during the grain filling period, the reduction in the number of seeds, the weight of 1000seeds, the reduction in density and other factors associated with grain yield (Kumar et al., 2013; Hassan et al., 2014 and Kerr et al., 1992).

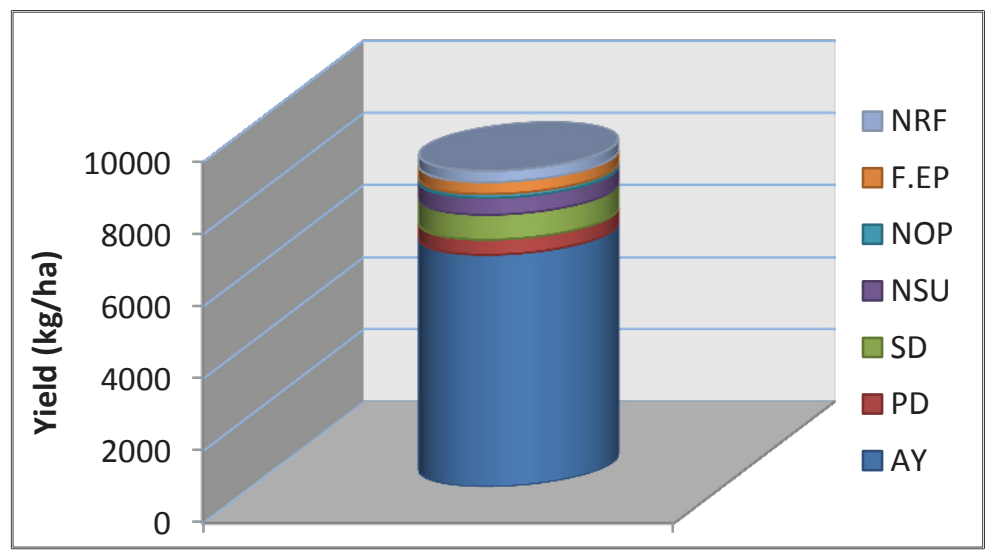

Fig. 7. The contribution of the major limiting factors to wheat yield gap. 


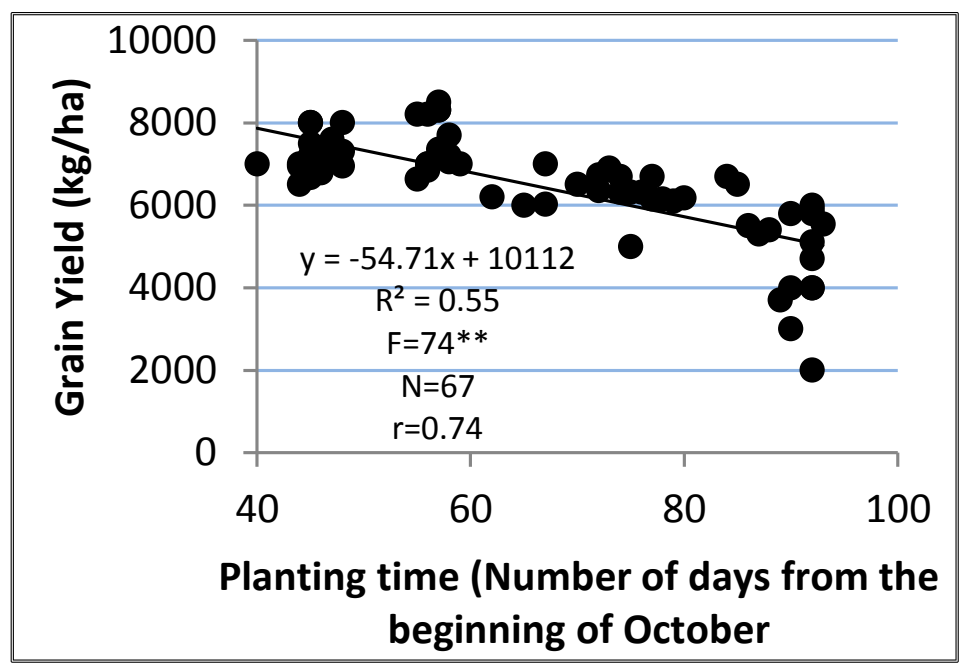

Fig. 8. Regression relationship of planting date and yield in the farmers' fields.

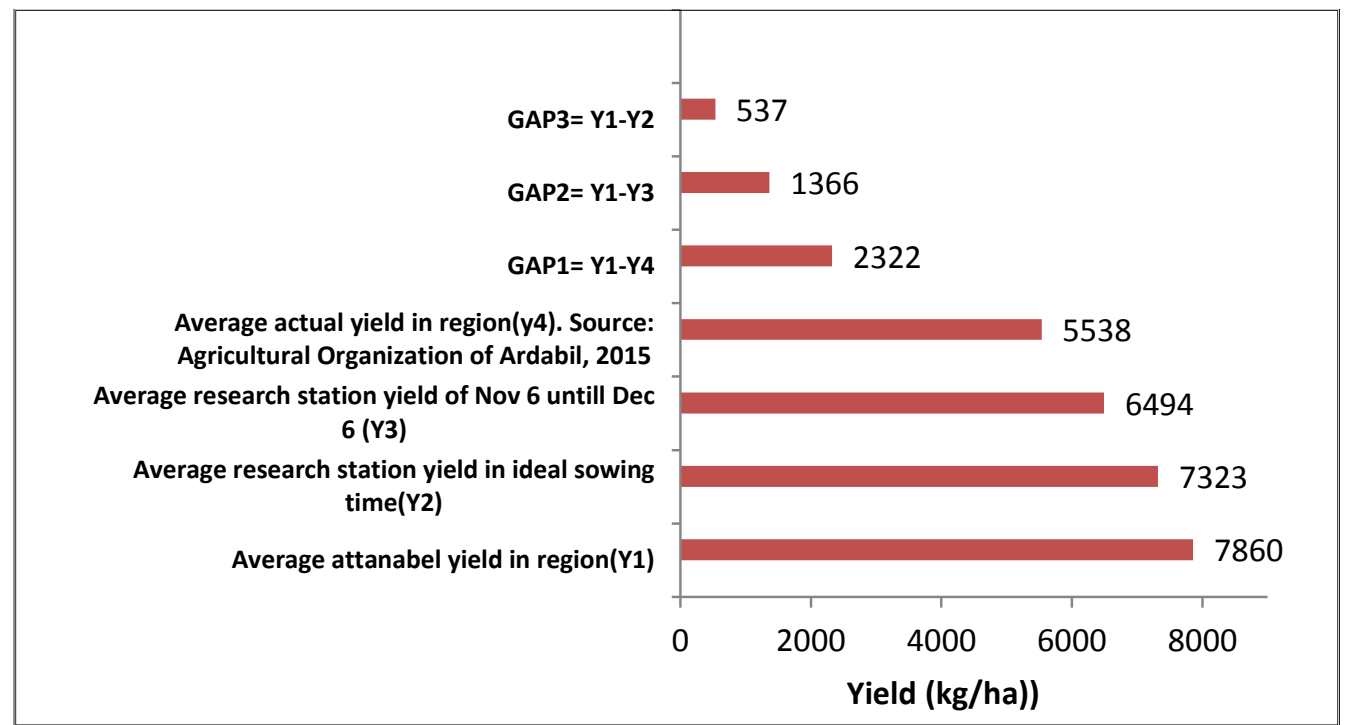

Fig. 9. Effect of planting date on wheat yield and yield gaps.

\section{Spike density and yield gap}

Spike density per unit area is one of the factors affecting grain yield. The results of field survey (Fig. 10) show that by increasing the density of wheat spikes per square meter, yield increases significantly and linearly $(\mathrm{P}<0.01)$. Among the variables examined in the Table 1 , removable spike density had the highest proportion (29.7\%) in creating the gap between the actual yield and attainable yield. Spike Density in wheat is mainly affected by planting date. The data obtained in the field survey showed that wheat farmers who planted on an optimal date (from 15 November to 15 December) had more spike density and greater yield.

\section{Fertilizer aplication and yield gap}

In the study area, the application of fertilizer (Urea) was done differently. One of the reasons for yield variations between farms is due to the variation of $\mathrm{N}$ fertilizer management such as splitting, timing and amount of $\mathrm{N}$ fertilizer application. High yield, profitability and sustainability are the important effects of split application of urea fertilizer. Using urea in two or three phases, helps producers increase productivity of plants, increase yield and reduces wasting urea by leaching, volatilization and denitrification (Shirinzadeh et al., 2017). According to Fig. 11, the range of nitrogen fertilizer use was $550 \mathrm{~kg}$ the fields. The region farmers have an average consumption 
of $356 \mathrm{~kg}$ urea fertilizer. According to the third quartile, $75 \%$ of farms had urea consumption of $450 \mathrm{~kg}$. The results of biomass analysis (Fig. 12) of different farm fields indicated that maximum nitrogen recovery efficiency $(224 \mathrm{~kg} / \mathrm{ha})$ observed in November sowing date with $350 \mathrm{~kg} / \mathrm{ha}$ of urea fertilizer in three stages, tillering, stem elongation and booting. Also, nitrogen use efficiency among the farmers in the region was an average of $16.6 \mathrm{~kg} /$ $\mathrm{kg}$ of nitrogen. While, the figure in England was reported at $26.5 \mathrm{~kg} / \mathrm{kg}$ of nitrogen (SylvesterBradley \& Kindred, 2009), it has been shown than manure increase yield (Zingore et al., 2008). The present study, also conveys that farmers who applies manure in large amount and frequently apply it less efficiently than those who apply it in less quantities.

Suitable agronomic management by using fertilizer can play an important role in reducing the yield gaps in the region through increasing actual yield. Optimization of nitrogen with the nitrogen supply in the crop can improve the recovery of nitrogen efficiency. So split use of nitrogen fertilizer is an effective way to increase the efficiency of urea use which will significantly be effective in disease control and prevention of water waste in irrigation of wheat, reducing the risk of freezing and ultimately increasing wheat yield (Shirinzadeh et al., 2017). In Parsabad Moghan (Fig. 13), Based on different $\mathrm{N}$ rates (120, 240 and $360 \mathrm{~kg} \mathrm{ha}^{-1}$ ) and application time (T1, T2, $\mathrm{T} 3$ and T4), a wide range of wheat grain yield was obtained; grain yield ranged from $3890 \mathrm{~kg} \mathrm{ha}^{-1}$ to $8300 \mathrm{~kg} \mathrm{ha}^{-1}$ (Fig 1). Result of $\mathrm{N}$ rates and its timing interaction effects indicates that maximum wheat grain yield was obtained from $360 \mathrm{~kg} \mathrm{~N} \mathrm{ha}^{-1}$ when it was completely used in T2 (application in tillering, steam elongation and grain filling in three stages) as well as T4 (nitrogen application in sowing, tillering and grain filling).

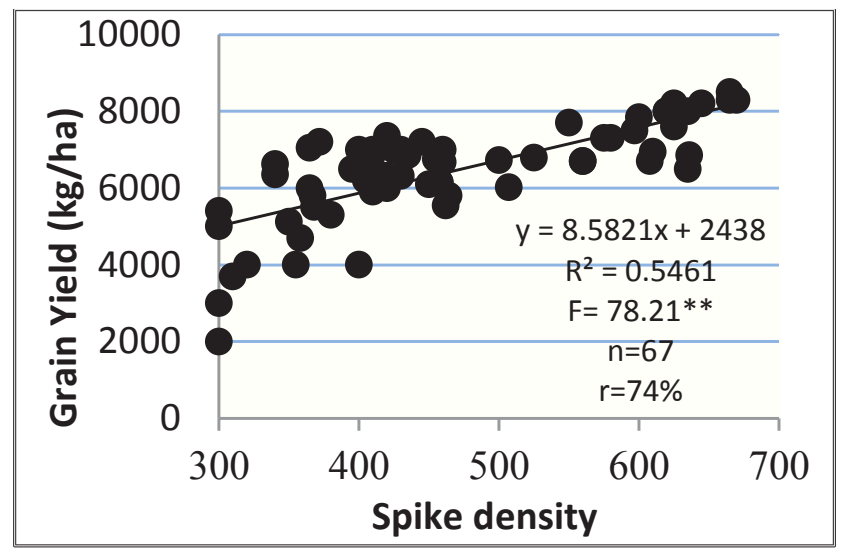

Fig. 10. Regression relationship of spike density and yield in the farmers' fields.

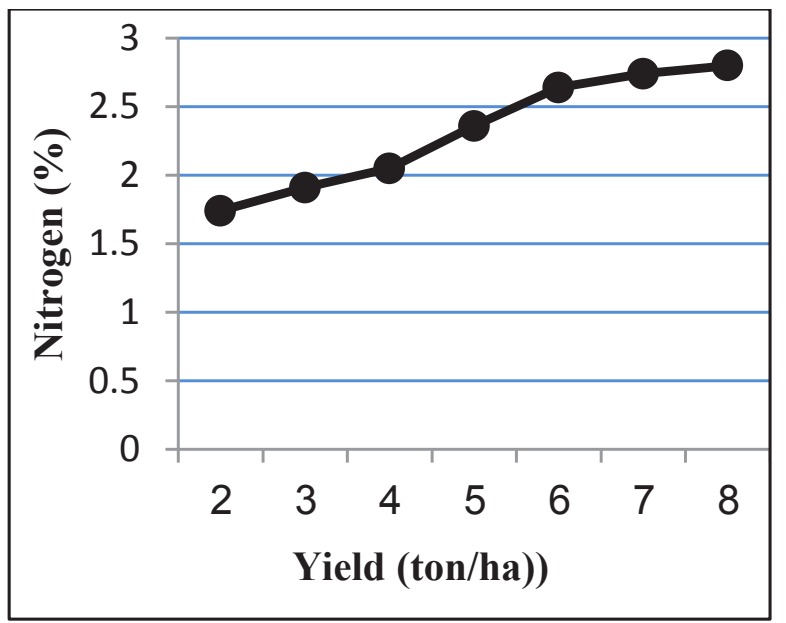

Fig. 11. Consumption of urea fertilizer in field of selected farms. 


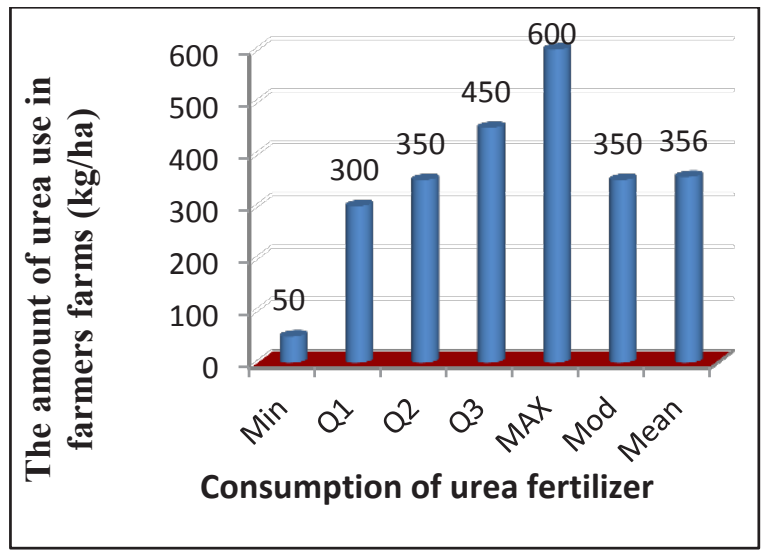

Fig. 12. Percentage of nitrogen in wheat grain and straw at different yield levels.

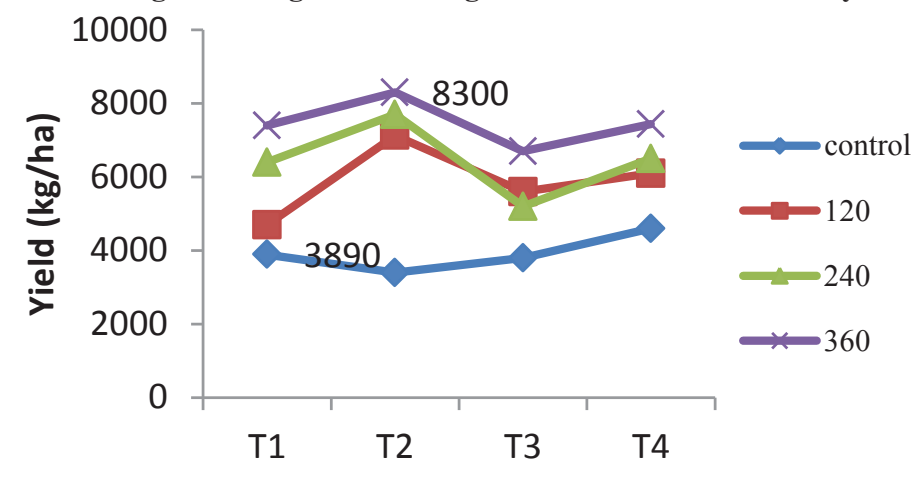

Nitrogen timing treatments

Fig. 13. Nitrogen timing treatments: $T 1=$ Sowing, tillering, stem elongation; $T 2=$ Tillering, stem elongation, grain filling; T3= Sowing, stem elongation, grain filling and T4= Sowing, tillering, grain filling.

Regression relationship of split urea fertilizer after planting reveals significant relationship between independent variable and yield in farmers' fields. Farms in which used urea fertilizer at right time and replication, had a higher yield (Fig 14). The results of the comparative analysis showed that optimum nitrogen fertilizer consumption could eliminate $20 \%$ of wheat yield in the studied area (Table 1) (Hajjarpoor et al., 2016). Using this method stated that improper management of nitrogen consumption caused a $25 \%$ decrease in wheat yield in Gorgan province. Torabi et al. (2011) reported the impact of this restriction in the same region $18 \%$.

\section{Land preparation}

Based on comparative analysis, land preparation operation were one of the factors affecting grain yield. Operations management of agricultural land which in turn affects the management of water, machinery, density and row spacing is the result of the implementation of incorrect crop rotation imposing the late planting of wheat in a bad weather conditions and low temperature to the farmers of the region. This condition increased land preparation operations for wheat. Figure 15 shows the regression relationship between land preparations and planting time which indicates the significant relationship between this independent variable and yield in agricultural fields $(\mathrm{P}<0.01)$. By increasing the number of land preparation practices, the yield has decreased.

Some researchers noted heavy traffic, increase the intensity of the physical structure of the soil, unsuitable and improper soil conditioning agent, culture conditions as the factors affecting root growth and plant tissues (Kay et al., 2006). Early planting, suitable farm management (Anderson, 2010), results in reducing the number of operations for providing land, improved physical and chemical properties (Arvidsson et al., 2014 and Romaneckas et al., 2012) of soil (Morris et al., 2010) and biological properties (Melero et al., 2009 and Morris et al., 2010), environmental regulations and maintaining the optimum rate of 
nitrogen (Carver, 2010). Besides improving soil structure, air and water infiltration and biological and microbial activities (Soane et al., 2012), reduces mineralization and increase soil organic carbon in the long term which has impact on the activity of soil microbial biomass (Alvaro-Fuentes et al., 2013; Melero et al., 2009; Swedrzynska et al., 2013 and Carver, 2010).

\section{Experiences farmers}

Technology transfer can be slow in farmers of smallholdings. Good wheat agronomy requires moderately high levels of farmer skill (especially in pest control) and given that these crops in this region are primarily grown by farmers of smallholdings. In this study, there was an inversely significant relationship between the farmer's experience and crop yield, which was probably due to the lack of updated information among experienced farmers. It seems that the old farmers are more willing to traditional agriculture compared to farmers with less work experience. The average age of farmers was 47.52. Young farmers with a college education had more yield than old ones. According to field study, product performance significantly decreased with increasing farmers' age and experience.
Older farmers are more likely to use traditional methods and show less interest in application of new findings. Based on the variable of farmer's experience, wheat yield gap was 3.14 percent in this study (Table 1). Nekahi et al. (2015) found similar results in Bandar Gaz in Golestan Province.

\section{Fungicide application}

Because of the sensitivity of cultivars to disease, especially Fusarium and wheat rust in Moghan, yield is greatly affected by this variable. According to the survey on wheat and comparative analysis with stepwise regression method, frequency, type and dose of fungicides to control the disease had $13.4 \%$ rate of impact in controlling the diseases (Table 1 and Fig. 15). Correlation between repeated fungicides and grain yield was $75 \%$ and farmers could successfully decrease yield gap by $311 \mathrm{~kg}$ by increasing the number of fungicide consumption. Figure 16 indicates a significant regression relationship between fungicide and grain yield and shows a growing function with the use of fungicides. HGCA et al. (2001) stated in their experiments that the effect of fungicide on disease control was $15 \%$.

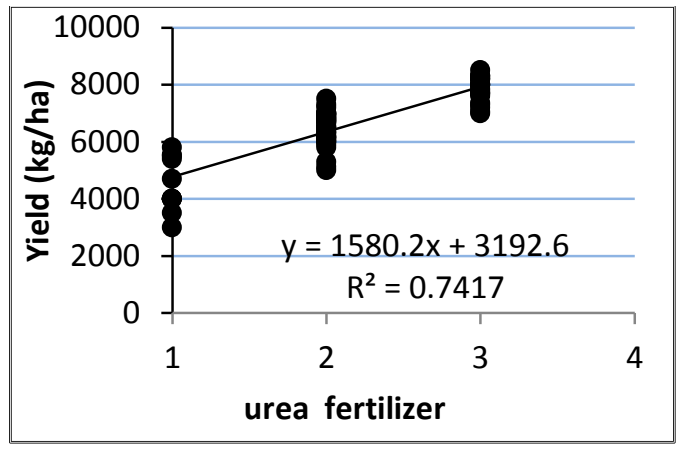

Fig. 14. Regression relationship between splitting urea fertilizer use and yield in the farmers' fields.

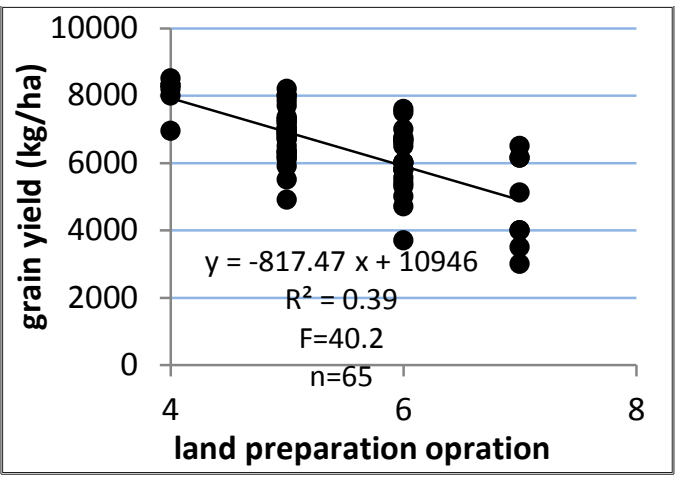

Fig. 15. Regression relationship between number of the land preparation operation and yield in the farmers' fields. 


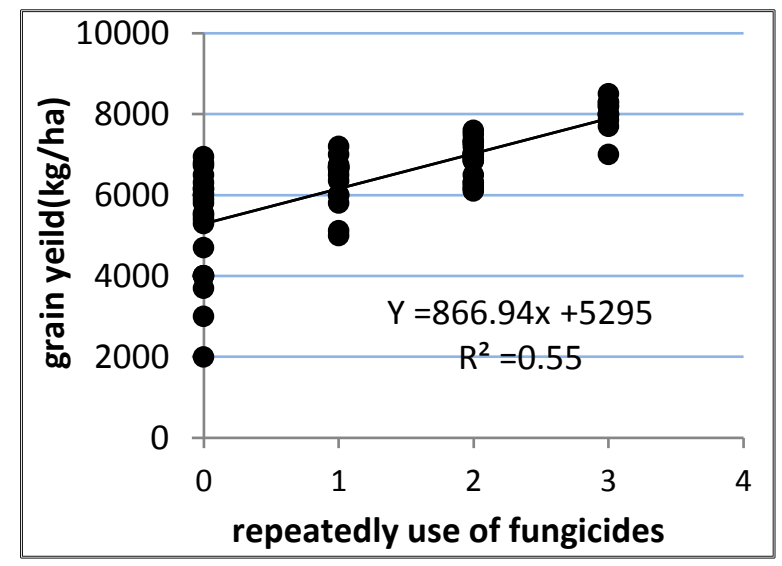

Fig.16. Regression Relationship between repeatedly use of fungicides and grain yield in the farmers' fields.

\section{Conclusion}

The yield gaps study on wheat in Parsabad Moghan during 2013-2015 identified six management and biophysical constraints. The total estimated yield gap of $2317.42 \mathrm{~kg} / \mathrm{ha}$ appear to be following management and biophysical constraint (Fig. 4): Planting time (18\%), Spike density $(29.7 \%)$, number of split application of urea $(20 \%)$, Land preparation operations $(4.6 \%)$, farming experience $(14.3 \%)$ and repeated use of fungicides for wheat (13.4). Therefore to narrow yield gap of wheat in the study area, by selecting suitable planting date, farmers can be hopeful to $18 \%$ of increase in yield per hectare. The optimum planting date in the area (Moghan) is from $6^{\text {th }}$ of November to $6^{\text {th }}$ of December. But it is better to start planting date from the first half of November and end on the first week of December. Creating high density can be possible by planting date, genotype and seeding rate. In this way, we can create the appropriate density of 29.7 percent (690.46 kg per hectare) to reduce the yield gap in the area. High yield, profitability and sustainability are some of the important effects of split urea application. Using urea in two or three phases will help producers increase productivity of plants for nitrogen, increase yield and reduce waste in the form of urea fertilizer leaching, volatilization and denitrification. Based on production model, split use of fertilizer will increase yield by $20 \%$, or $464.32 \mathrm{~kg} \mathrm{ha}^{-1}$. Reducing the number of operations was effective in improving the yield gap at a rate of $4.6 \%$. The cultivars used in Moghan are susceptible or moderately susceptible to Fusarium. The results showed that due to lack of genetic resistance to disease, by selecting suitable time, amount and type of fungicide used to control these diseases, we can be hopeful to partly chemical control methods, increase yield. Frequent use of appropriate fungicides was effective in controlling Fusarium with the rate of $13.4 \%$. Farmers' experience is also one of the factors affecting the yield gap in Moghan. Old and experienced farmer more likely use traditional ways without regarding the recommendations of the technical experts while they should have updated information on to reduce yield gap.

Acknowledgement: We would like to thank the collaborating farmers, Agricultural Organization of Ardabil, Ardabil Agricultural Research, Education and Extension Organization, Science and Research Branch, Islamic Azad University, Tehran, Iran and Thesis Advisor Dr Hossein Heidari Sharif Abad for providing information, support and data

\section{$\underline{\text { References }}$}

Alvaro-Fuentes, J., Morell, F.J., Madejón, E., Lampurlanés, J., Arrúe, J.L. and Cantero-Martínez, C. (2013) Soil biochemical properties in a semiarid Mediterranean agro- ecosystem as affected by Long term tillage and N fertilization. Soil \& Tillage Research, 129, 69-74.

Arvidsson, J., Etana, A. and Rydberg, T. (2014) Crop Yield in Swedish Experiments with Shallow Tillage and No-tillage 1983-2012. Europe. J. Agron., 52, 307-315.

Anderson, W.K. (2010) Closing the gap between actual and potential yield of rainfed wheats. The impacts of environment, management and cultivar. Field Crop Research 116, 14-22. 
Carver, M., (2010) United Kingdom. Pp. 503-320 in world wheat book. Volume 1, ed. By A.P. Bonjean, W.J. Angus and M. van Ginkel. Lavoisier publishing: Paris.

Carberry, P.S., Bruce, S.E., Walcott, J.J. and Keating, B.A. (2011) Innovation and productivity in dryland agriculture: a return-risk analysis for Australia. Journal of Agricultural Science 149, 77-89.

Cassman, K. G., Doberman, A., Walters, D. T., and Yang, H. (2003) Meeting cereal demand while protecting natural resources and improving environmental quality. Annu. Rev. Environ. Resour. 28, 315-358.

De Bie, C.A.J.M. (2000) Yield gap studies through comparative performance analysis of agrocosystems. International Institute for Aerospace and Earth Science (ITC), Enschede. The Netherlands. $234 p$.

Fanadzo, M., Chiduza, C., Mnkeni, P.N.S., Van der Stoep, I., Stevens, J. (2010) Crop production management practices as a cause for low water productivity at Zanyokwe Irrigation Scheme. Water SA. 36, 27-36.

Fischer, R.A., Byerlee, D., and Edmeades, G.O. (2009) Can Technology Deliver on the Yield Challenge to 2050? Expert meeting on how to feed the world in 2050. Rome: Food and Agriculture Organization of the United Nations, Economic and Social Development Department.

Fischer, R.A., Byerlee, D. and Edmeades, G.O. (2014) Crop yields and global food security: will yield increase continue to feed the world? ACIAR Monograph No. 158. Australian Centre for International Agricultural Research: Canberra. xxii +634 pp.

Flowers, M., James, C., Petrie, S. Machado, S., and Rhinhart, K. (2006) Planting date and seeding rate effects on the yield of winter and spring wheat varieties results from the 2005-2006 cropping year. Agri. Res. 12(2): 72-74.

Hassan, M., Wahla, A.J. Waqar, M.Q., and Ali, A. (2014) Influence of Sowing Date on the Growth and Grain Yield Performance of Wheat Varieties under Rainfed Condition. Sci. Tech. and Dev.33 (1): 22- 25.

Hajjarpoor, A., A. Soltani and B. Torabi. 2016. Using boundary line analysis in yield gap studies: Case study of wheat in Gorgan. Electronic J. Crop Prod. 8:
183-201. (In Persian with English abstract).

HGCA (Home Grown Cereal Authority). (2011) Recommended list winter wheat 2011/12. At $<$ www. hgca.com/publications/documents/varieties/RL_ tables_2011-12.pdf>, accessed 6 July 2011.

Kayiranga, D. (2006) The effects of land factors and management practices on rice yields. International Institute for Geo-Information Science and Earth Observation Enschede (ITC). The Netherlands. 72 p.

Kay, B.D., Hajabbasi, M.A., Ying, J., and Tollenaar, M. (2006) Optimum versus non- limiting water contents for foot growth, biomass accumulation, gas exchange and the rate of development maize (zea mays 1.). Soil \&Tillage Research 88, 42-54.

Kerr N. J., K. H. Siddique and R. J. Delane. (1992) Early Sowing With Wheat Cultivars of Suitable Maturity Increases Grain Yield of Spring Wheat in a Short Season Environment. Australian Journal of Experimental Agriculture. 32, 717 - 733.

Kumar, S., Alam, P., and Ali, N. (2013) Response of Wheat (Triticum aestivum L. emend. Fori \& Paol.) Varieties to Sowing Dates. Journal of Research (BAU). 25 (1),56 -59.

Licker, R., Johnston, M., Foley, J.A., Barford, C., Kucharik, C.J., Monfreda, C., et al. (2010) Mind the gap: how do climate and agricultural management explain the 'yield gap 'of crop lands around the world? Glob. Ecol. Biogeogr. 19, 769-782.

Mahloji, M., Mousavi, S.F., and Karimi, M. (2000) The effect of planting dateand drought stress on grain yield and yield components of snap bean. J. Sci. Technol. Agr. Nat. Reso. 4,1. 57-67.

Mueller, N.D., Gerber, J.S., Johnston, M., Ray, D.K., Ramankutty, N., Foley, J.A. (2012) Closing yield gaps through nutrient and water management. Nature. 490 (7419),254-257.

Melero, S., Vanderlinden, K., Ruiz, J.C., and Madejón, E. (2009) Soil Biochemical Response after 23 Years of Direct Drilling under a Dryland Agriculture System in Southwest Spain. J. Agric. Sci, 147(1), 9-15.

Morris, N.L., Miller, P.C. H., Orson, J.H. and FroudWilliams, R.J. (2010) The Adoption of Noninversion Tillage Systems in the United Kingdom and the Agronomic Impact on Soil, Crops and the 
Environment: A Review. Soil \&Tillage Research, 108, 1-15.

Nekahi. M.Z. Soltani. A., Siahmargoie. A., Bagerani, N. (2015) Yield gap associated with crop management in wheat (Case study: Golestan province-Bandargaz). Electronic J. Crop Prod. 7, 135-156. (In Persian with English abstract).

Patrignani, P., Lollato, R.P., Ochsner, T.E., Godsey, C.B., and Edwards, J.T. (2014) Yield gap and production gap of rainfed winter wheat in the Southern Grain Plains. Agron. J. 106, 1329-1339.

Ray, D.K., Mueller, N.D., West, P.C., and Foley. J.A. (2013) Yield Trends Are Insufficient to Double Global Crop Production by 2050. PLOS ONE 8(6): e66428.

Rezaie, A., and Soltani, A. (2007) An Introduction to Applied Regression Analysis. Isfahan University of Technology Press. Isfahan. Iran. P: 294. (In Persian) 16.

Romaneckas, K., Avižienyte, D., Šarauskis, E., Martinkus, M., Pilipavicius, V., damaviciene, A. and Sakalauskas, A. (2012) Impact of Ploughless Tillage on Soil Physical Properties and Winter Wheat Productivity. J. Food Agric. Environ., 10,501-504.

Shirinzadeh, A., Heidari Sharif Abad, H., Normohamadi, G., Majidi Haravan, E., Madani, H. 2017. The estimation of wheat yield gap and introducing of strategy to close it at Moghan region. Ph.D. Thesis, 1Department of Agronomy, Science and Research Branch, Islamic Azad University, Tehran.

Soane, B.D., Ball, B.C., Arvidsson, J., Basch, G., Moreno, F. and Roger-Estrade, J. (2012) No-till in Northern, Western, and South-western Europe: A Review of Problems and opportunities for crop production and the environment. Soil and Tillage Research, 118, pp. 66-87.

Swedrzynska, D., Małecka, I., Blecharczyk, A., Swedrzynski, A. and Starzyk, J. (2013) The Effect of Various Long-term Tillage Systems on Some Chemical and Biological Properties of Soil. Pol. J. Environ. Stud., 22, 1835-1844.

Sylvester-Bradley, R., and Kindred, D.R. (2009) Analysing nitrogen responses of cereals to prioritize routes to the improvement of nitrogen use efficiency. Journal of Experimental Botany. 60, 1939 -1951.

Sharma, R.C., Crossa J., Velu, G., Huerta-Espino, J., Vargas, M., Payne, T.S., and Singh, R.P. (2012) Genetic gains for grain yield in CIMMYT spring bread wheat across international environments. Crop Science 52, 1522-1533.

Torabi, B., Soltani, A., Galeshi, S., and Zeinali, E. (2011) Analyzing wheat yield constraints in Gorgan. EJCP. 4,1-17.

Tilman, D., Balzer, C., Hill, J., Befort, B.L. (2011) Global food demand and the sustainable intensification of agriculture. Proc Natl Acad Sci USA. Dec $13^{\text {th }} ; \mathbf{1 0 8}$ (50), 20260-4.

Van Ittersum, M.K., Cassman, K.G., Grassini, P., Wolf, J., Tittonell, P., and Hochman, Z. (2013) Yield gap analysis with local to global relevance, a review. Field Crops Res. 143, 4-17.

Yang, W., Peng, S., Laza, R.C., Visperas, R.M., and Dionisio-Sese, M. (2008) Yield gap analysis between dry and wet season rice crop grown under high-yielding management conditions. Agron.J. 100, 1390-1395.

Zingore, S., Delve, R.J., Nyamangara, J., Giller, K.E. (2008) Multiple benefits of manure: the key to maintenance of soil fertility and restoration of depleted sandy soils on African smallholder farms. Nutr Cycl Agroecosyst. 80,267-282

(Received 2/ 5/2018; accepted 11/11/2018) 